\title{
Energy Audit Application for Rice-Wheat Cropping System
}

\author{
RAJESH U. MODI ${ }^{*}$, MUDASIR ALI', \\ RAGHUVIRSINH P. PARMAR ${ }^{1}$ and SHARAD KUMAR NAMDEV ${ }^{2}$
}

\begin{abstract}
${ }^{1}$ Department of Farm Machinery and Power Engineering, College of Agricultural Engineering and Technology, Punjab Agricultural University, Ludhiana, Punjab, India.

${ }^{2}$ Department of Farm Machinery and Power Engineering, Zila Parishad Krishi Mahavidhalaya Banda, Bundelkhand University Jhansi, Uttar Pradesh, India.
\end{abstract}

\begin{abstract}
This computer application deals with energy auditing for rice-wheat cropping system. Computing different input parameters for the crop production system in terms of energy requirement (MJ/ha) can be done by using this computer application. The developed application was found to be a simple, easy and user-friendly with appropriate output units. It works efficiently and gives the desired output in terms of energy consumption ( $\mathrm{MJ} / \mathrm{ha}$ ). The advantage of this application is to decide the inputs on the basis of energy consumption before performing actual cultivation practice using the last season data. Moreover, using this package energy budget difference and comparison of subsequent production seasons can be achieved. The computer application was developed using Visual Basic, which allows the user to calculate total energy use efficiency, specific energy and different energy ratios in a particular cropping system.
\end{abstract}

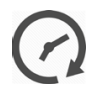

Article History

Received: 8 October 2018 Accepted: 7 November 2018

\section{Keywords}

Computer Application, Energy Analysis, Energy Requirement, Rice-Wheat, Visual Basic.

\section{Introduction}

Energy is recognized as being the vital and valuable input source in a crop production system. Successful crop production consumes energy directly or indirectly from combination of various sources like seed, farmyard manure, fertilizer, plant protection, irrigation and machinery. Agriculture production is both energy dependent and demanding process.
Energy is consumed as well as supplied back by agriculture sector in the form of bioenergy. ${ }^{1}$ Efficient and precise energy input is critical part for economical and sustainable crop production. Generally, energy required in agriculture has been classified as direct and indirect. Moreover, direct energy releases energy directly whereas indirect energy releases energy through a conversion

CONTACT Rajesh U. Modi rmodi0701@gmail.com 9 Department of Farm Machinery and Power Engineering, College of Agricultural Engineering and Technology, Punjab Agricultural University, Ludhiana, Punjab, India.

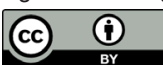

(C) 2018 The Author(s). Published by Oriental Scientific Publishing Company

This is an $\partial$ Open Access article licensed under a Creative Commons license: Attribution 4.0 International (CC-BY).

Doi: http://dx.doi.org/10.13005/ojcst11.04.06 
process. Direct energy provides energy to accomplish various farm operations such as tillage, sowing, weeding, irrigation, crop protection, threshing and harvesting. Whereas, indirect energy provides energy includes the energy required for packaging and transportation of the seed, fertilizer, pesticides and machinery. However, energy is also classified as renewable or non-renewable energy sources. Energy sources like human, animal, farmyard manure and seed are considered as renewable energy sources whereas fossil fuels, electricity, farm machinery including tractor, chemicals and fertilizers are falls under non-renewable energy sources. The energy analysis enhances energy productivity by minimizing the energy inputs effectively in a crop production system. The parameters such as specific energy and energy ratio define the efficient work of the system. An estimation of energy input in agriculture sector is more challenging as the production is being increasing day by day through the use of various commercial technologies. Therefore, increased agricultural production requires greater energy inputs in a developed and efficient manner. However, the energy use pattern can be different for various farm operations which would lead to a change in energy requirement for a particular operation. Although, for crop production systems the energy requirement in Indian agriculture may increase further. ${ }^{2}$

Rice-wheat cropping system is reported as the major cropping system in the south Asian subcontinent. It covers about 13.5 million hectares in the Indo-Gangetic Plains, of which India has 10 million hectares, Pakistan has 2.2 million hectares, Bangladesh holds 0.8 million hectares and Nepal has 0.5 million hectares. These countries accounted more than $25-33 \%$ of total rice and wheat production. In this system, rice covered about $33 \%$ and wheat $42 \%$ of the total area. It was found to be dominant in the northern part of India with devoting almost $75 \%$ of total country's food grain production. ${ }^{3}$ As an individual view, rice and wheat are the major crops in the world grown over 163 million hectares and 220 million hectares harvest area, respectively. The total production in the world is 741 million tons and 729 million tons of rice and wheat, respectively. Out of this, India ranked second in both the crop production systems. Rice comprises 43.9 million hectares of harvest area whereas wheat comprises 30.5 million hectares with the production of 104.3 and 95.9 million tons of paddy and wheat, respectively. ${ }^{4}$ However, Punjab has the highest productivity in rice with the production of 18.8 million tons and even more on the cultivated area of 3.04 million hectares. ${ }^{5}$ Achieving this needs more energy consumption where rice-wheat cropping system gives the highest net return energy (102862 MJ/ ha). ${ }^{6}$ The field experiment on energy and economic analysis conducted in wheat production in Chhattisgarh, India and concluded that Zerotillage treatment is one of the energy efficient and economical conservation tillage machinery. ${ }^{7}$ However, rice-wheat production demand will increase as the country progresses, as so energy. Therefore, it is important to calculate the energy requirement before the actual steps being taken towards execution of unit operations in crop production. Rice crop consumes more than $90 \%$ of the total energy input only from commercial sources and remaining from non-commercial sources. However, this energy analysis is tedious method if done manually. A program was developed in Visual Basic to determine the energy requirement for sugarcane production. ${ }^{8}$ However, this computer program was unable to calculate energy consumption in ricewheat cropping system. In the view of above, a user-friendly computer application was developed to assist in computing energy analysis using Visual Basic 2015 as a programing language. The main objective of this study was to provide easy and efficient energy input-output analysis in rice-wheat crop production system.

\section{Materials and Methods \\ Method of Calculation and Theoretical Considerations}

The data regarding energy equivalents for the study were taken from the various literature cited as shown in Table1. Furthermore, energy was calculated on the basis of energy equivalents as referred. Production factors includes human (man-h), tractor (h), machinery $(h)$, diesel consumption (liter), farmyard manure $(\mathrm{kg})$, chemical $(\mathrm{kg})$, fertilizer $(\mathrm{kg})$, seed $(\mathrm{kg})$, electricity (kWh), grain (rice or wheat) yield $(\mathrm{kg})$ and straw yield $(\mathrm{kg})$. In order to obtain the parameters such as energy ratios and specific energy (MJ/kg) 
Table 1. Energy Equivalents of Inputs

\begin{tabular}{lllccc}
\hline SI. No. & Input & Unit & Abbreviation & $\begin{array}{c}\text { Energy equivalent } \\
\text { (MJ/Unit) }\end{array}$ & Reference \\
\hline 1. & Human & man-h & $\mathrm{E}_{\mathrm{qh}}$ & 1.96 & 9 \\
2. & Animal (large) & $\mathrm{pair}-\mathrm{h}$ & $\mathrm{E}_{\mathrm{qa}}$ & 14.05 & 9 \\
3. & Diesel & $l$ & $\mathrm{E}_{\mathrm{qd}}$ & 56.31 & 10 \\
4. & Electricity & $\mathrm{kWh}$ & $\mathrm{E}_{\mathrm{qe}}$ & 11.93 & 10 \\
5. & Seed & $\mathrm{kg}$ & $\mathrm{E}_{\mathrm{qg}}$ & 14.7 & 9 \\
6. & Farmyard manure & $\mathrm{kg}$ & $\mathrm{E}_{\mathrm{qf}}$ & 0.3 & 10 \\
7. & Fertilizer & $\mathrm{kg}$ & $\mathrm{E}_{\mathrm{qc} 2}$ & 60.60 & 10 \\
8. & Chemical & $\mathrm{kg}$ & $\mathrm{E}_{\mathrm{qc1}}$ & 199 & 10 \\
9. & Tractor & $\mathrm{kg}$ & $\mathrm{E}_{\mathrm{qt}}$ & 68.4 & 9 \\
10. & Machinery & $\mathrm{kg}$ & $\mathrm{E}_{\mathrm{qm}}$ & 62.7 & 12 \\
11. & Straw & $\mathrm{kg}$ & $\mathrm{E}_{\mathrm{qs}}$ & 12.5 & \\
\hline
\end{tabular}

the energy input and energy output (MJ/ha) as well as the yield $(\mathrm{kg} / \mathrm{ha})$ were used.

In the programming following formulas were used for further calculation

$$
\begin{aligned}
& E_{H}=E_{q h} \times H_{h} \\
& E_{A}=E_{q a} \times A_{h} \\
& E_{T}=\left(E_{q t} \times W_{t} \times W_{h t}\right) /\left(L_{t} \times W_{h y t}\right) \\
& E_{M}=\left(E_{q m} \times W_{m} \times W_{h m}\right) /\left(L_{m} \times W_{h y m}\right) \\
& E_{D}=E_{q d} \times F_{c} \\
& E_{F}=E_{q f} \times F_{q} \\
& E_{C 1}=E_{q c 1} \times C_{q 1} \\
& E_{C 2}=E_{q c 2} \times C_{q 2} \\
& E_{s}=E_{q g} \times S \\
& E_{E}=E_{q e} \times E_{h} \\
& E_{o p}=Y_{g} \times E_{q g} \\
& E_{o b}=Y_{s} \times E_{q S} \\
& E_{\text {total }}=E_{H}+E_{A}+E_{D}+E_{E}+E_{s}+E_{F}+E_{C 1}+E_{C 2}+E_{T}+E_{M}
\end{aligned}
$$

Direct energy $(\mathrm{MJ} / \mathrm{ha})=\mathrm{E}_{\mathrm{H}}+\mathrm{E}_{\mathrm{D}}+\mathrm{E}_{\mathrm{E}}$

Indirect energy $(\mathrm{MJ} / \mathrm{ha})=\mathrm{E}_{\mathrm{S}}+\mathrm{E}_{\mathrm{F}}+\mathrm{E}_{\mathrm{C} 1}+\mathrm{E}_{\mathrm{C} 2}+\mathrm{E}_{\mathrm{T}}+\mathrm{E}_{\mathrm{M}}$ Renewable $(\mathrm{MJ} / \mathrm{ha})=\mathrm{E}_{\mathrm{H}}+\mathrm{E}_{\mathrm{s}}+\mathrm{E}_{\mathrm{F}}$

Non-renewable $(\mathrm{MJ} / \mathrm{ha})=\mathrm{E}_{\mathrm{D}}+\mathrm{E}_{\mathrm{E}}+\mathrm{E}_{\mathrm{C1}}+\mathrm{E}_{\mathrm{C} 2}+\mathrm{E}_{\mathrm{T}}+\mathrm{E}_{\mathrm{M}}$ Commercial (MJ/ha) $=\mathrm{E}_{\mathrm{D}}+\mathrm{E}_{\mathrm{E}}+\mathrm{E}_{\mathrm{C} 1}+\mathrm{E}_{\mathrm{C} 2}+\mathrm{E}_{\mathrm{T}}+\mathrm{E}_{\mathrm{M}}+\mathrm{E}_{\mathrm{s}}$ Non-commercial $(\mathrm{MJ} / \mathrm{ha})=\mathrm{E}_{\mathrm{H}}+\mathrm{E}_{\mathrm{F}}$

Energy ratio for produce $=\mathrm{E}_{\mathrm{op}} / \mathrm{E}_{\mathrm{i}}$

Energy ratio for by-product $=\mathrm{E}_{\mathrm{ob}} / \mathrm{E}_{\mathrm{i}}$

Specific energy $(\mathrm{MJ} / \mathrm{kg})=\mathrm{Y}_{\mathrm{g}} / \mathrm{E}_{\text {total }}$

Where,

$A_{h}=$ Animal hour (large size pair)
$\mathrm{C}_{\mathrm{q} 1}=$ Chemical required

$\mathrm{C}_{\mathrm{q} 2}=$ fertilizer required

$\mathrm{E}_{\mathrm{A}}=$ Energy from animal pair (large size)

$\mathrm{E}_{\mathrm{C} 1}=$ Energy from chemicals

$\mathrm{E}_{\mathrm{C} 2}=$ Energy from chemical fertilizers

$E_{D}=$ Energy from diesel

$E_{E}=$ Energy from electricity

$E_{F}=$ Energy from farmyard manure

$E_{h}=$ Electricity hours

$E_{H}=$ Energy from human or labour

$E_{i}=$ Input energy

$E_{M}=$ Energy from machinery

$E_{o b}=$ Output energy for by-product (MJ/ha)

$E_{o p}=$ Output energy for produce (MJ/ha)

$E_{S}=$ Energy from seed

$\mathrm{E}_{\mathrm{T}}=$ Energy from tractor

$\mathrm{E}_{\text {total }}=$ Total energy ( $\left.\mathrm{MJ} / \mathrm{ha}\right)$

$\mathrm{F}_{\mathrm{c}}=$ Diesel fuel used

$F_{q}=$ Quantity of farmyard manure used

$\mathrm{H}_{\mathrm{h}}=$ Human hours

$L_{m}=$ Life of machine

$L_{t}=$ Life of tractor

$\mathrm{S}=$ Quantity of seed utilized

$\mathrm{W}_{\mathrm{hm}}=$ Machine working hours

$\mathrm{W}_{\mathrm{ht}}=$ Tractor working hours

$\mathrm{W}_{\text {hym }}=$ Machine working hours per year

$\mathrm{W}_{\text {hyt }}=$ Tractor working hours per year

$\mathrm{W}_{\mathrm{m}}=$ Weight of machine

$\mathrm{W}_{\mathrm{t}}=$ Weight of tractor

$Y_{\mathrm{g}}=$ Grain yield

$\mathrm{Y}_{\mathrm{s}}=$ Straw yield 


\section{Development of Application}

The computer application for energy audit (calculation) was developed for energy requirement in rice and wheat crop production systems. It was developed using Visual Studio 14.0 along with several sequential tabs to complete the process in order to obtain required energy input-output of the system. The tabs were precise intuitive and user friendly to enter the required values. This computer application starts with initializing welcome screen (Fig:1) and further instructions through navigation options while selecting a crop either rice or wheat. This application was separated in two modules i.e. input and output which are interdependent to each other. The first module comprises the input parameters needed for energy analysis such as human, animal, diesel, electricity, seed, farmyard manure, fertilizer, chemical, tractor, machinery, grain yield, straw yield etc. The total input energy can be calculated by providing these inputs in respective textboxes. However, navigation options are provided on the right side of the window itself, including 'Energy equivalents' button (Fig:2) to get all desired equivalents and finding the results by clicking the 'Calculate' button. For the calculation purpose, theoretical considerations were taken as discussed above. The Fig: 3 shows the flow chart of the developed computer application using Visual Basic ${ }^{\mathrm{TM}}$. The different sources were direct, indirect, renewable, non-renewable,

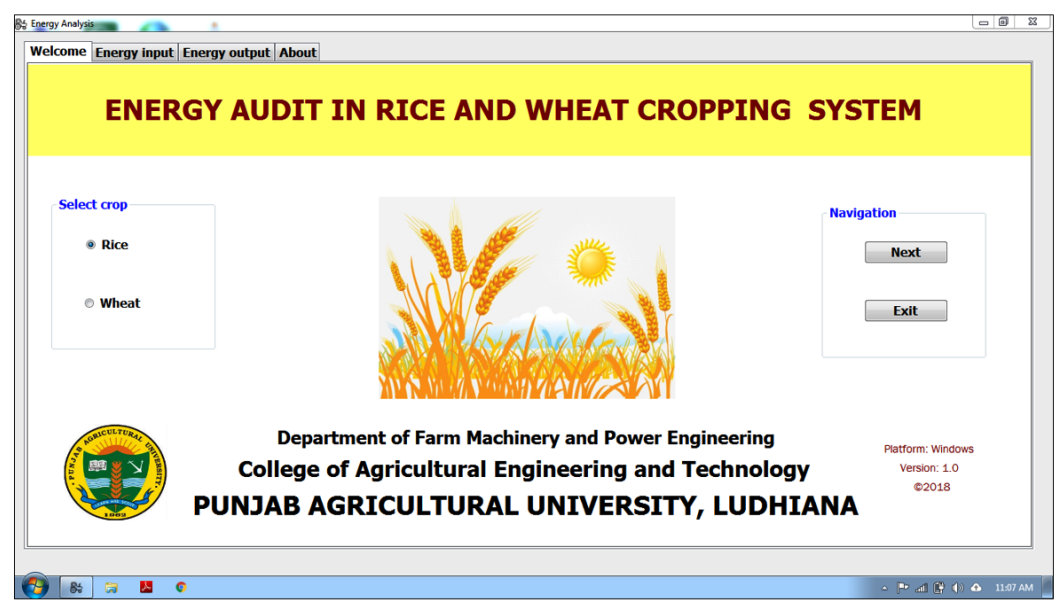

Fig:1 Initializing Screen of a Developed Computer Application in Visual Basic

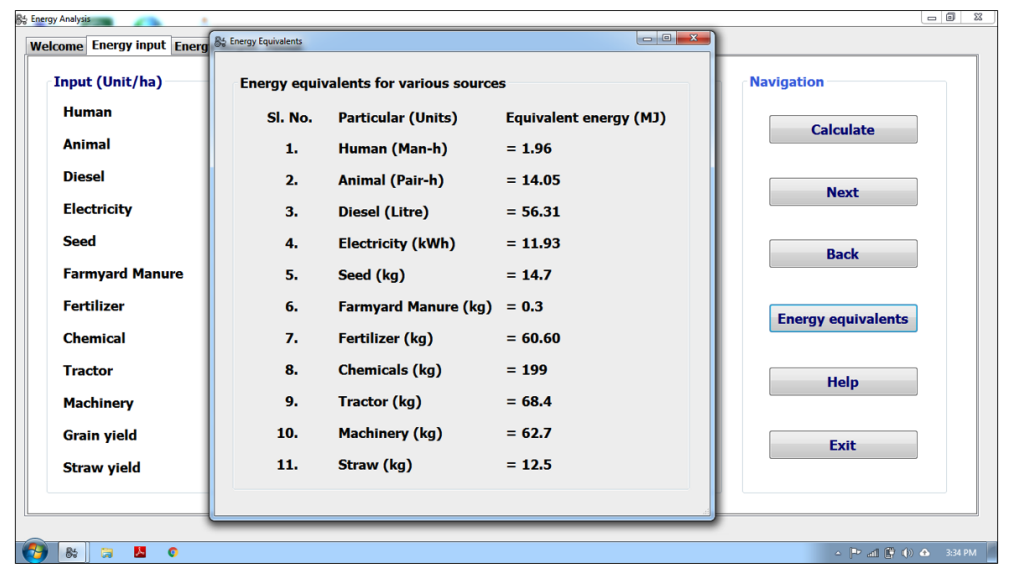

Fig:2 Energy Equivalents Screen Fetching Using ‘Energy Equivalents' Button in Navigation 


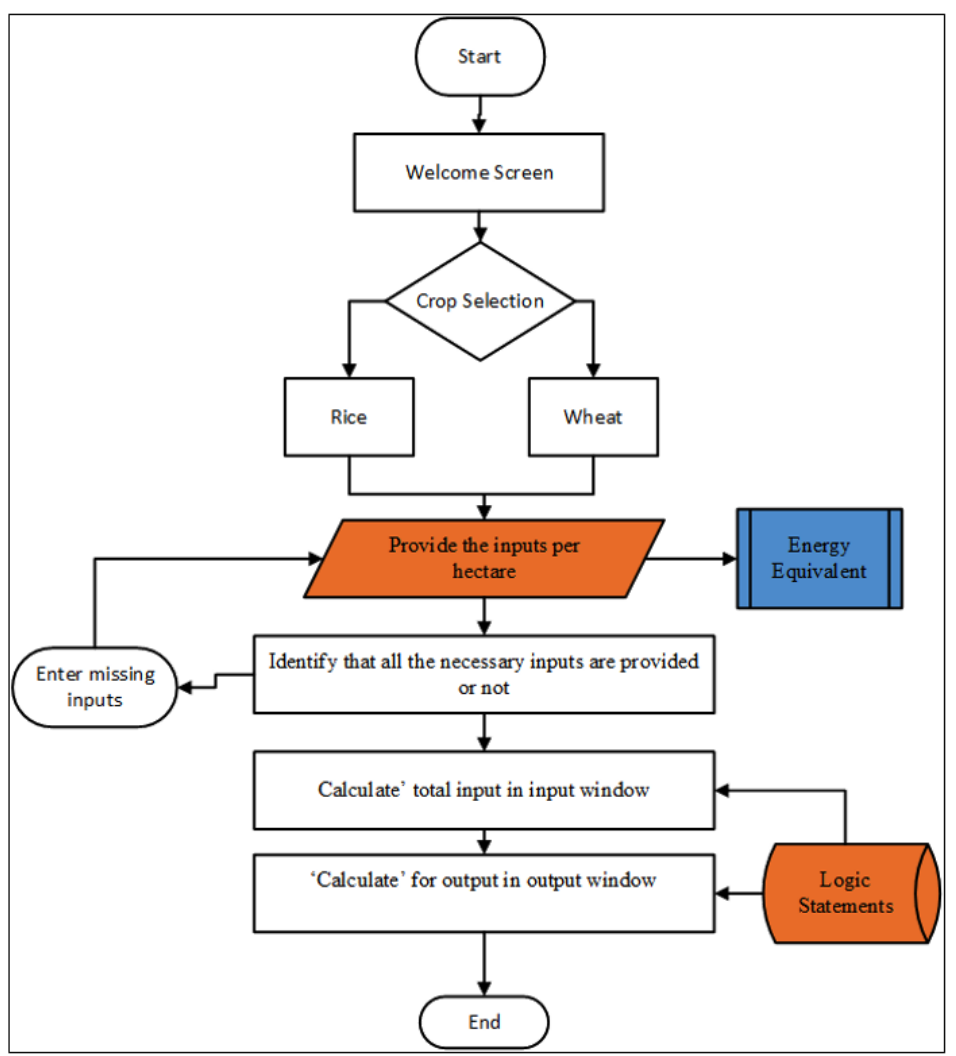

Fig:3 Flow Chart of the Energy Audit Application for Rice-Wheat Cropping System

Table 2. Amount of Different Input Values Per Hectare and Outputs Given by Computer Application for Rice

\begin{tabular}{lll}
\hline Particulars & Input Value (unit/ha) & Energy Output (MJ/ha) \\
\hline Human & $427(\mathrm{~h})$ & 836.92 \\
Animal & $00(\mathrm{~h})$ & 00 \\
Diesel & $81(l)$ & 4561.11 \\
Electricity & $683(\mathrm{kWh})$ & 8148.19 \\
Seed & $22(\mathrm{~kg})$ & 323.40 \\
Farmyard Manure & $3056(\mathrm{~kg})$ & 916.80 \\
Fertilizer & $131(\mathrm{~kg})$ & 7938.60 \\
Chemicals & $2.4(\mathrm{~kg})$ & 477.60 \\
Tractor & $11.2(\mathrm{~h})$ & 153.22 \\
Machinery & $40(\mathrm{~h})$ & 418 \\
Grain Yield & $5970(\mathrm{~kg} / \mathrm{ha})$ & 87759 \\
Straw Yield & $4963(\mathrm{~kg} / \mathrm{ha})$ & 62037.5 \\
& & \\
\hline
\end{tabular}


commercial and non-commercial energy sources. The efficiency of a system was found using output energy $(\mathrm{MJ} / \mathrm{ha})$, energy ratios and specific energy $(\mathrm{MJ} / \mathrm{kg})$. These calculations were obtained by clicking the 'Calculate' button as provided in a navigation option at the energy output module.

\section{Results and Discussion} Use of the Developed Computer Application Rice-wheat cropping system under large farm category (excluding animal power) was taken as an example to validate the developed energy audit software package. However, the motive behind the



Fig:4 Energy Input Screen for Rice Crop Production System

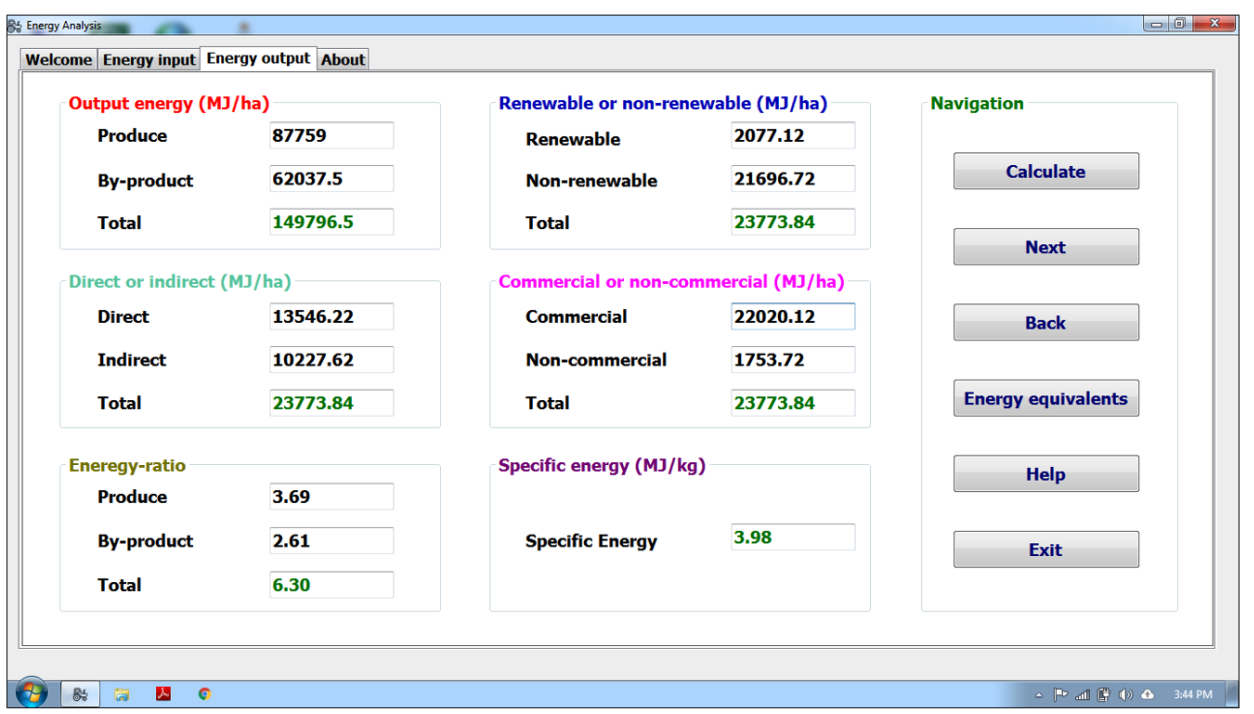

Fig:5 Energy Output Screen for Rice Crop Production System 
given input data as parameters discussed were taken for indicative purpose only and output obtained on the basis of different energy sources involved. The output screens and tables show that the developed computer application generated output values in agreement with the calculated values.

\section{Energy in Rice Cultivation}

As far as rice cultivation was considered in Indo-Gangetic Plains, puddling and transplanting operation are accomplished mostly with rotavator and manually, respectively. The programing windows for input parameters and different energy ratios



Fig:6 Source Wise Energy Consumption for Raising Rice

Table 3. Amount of Different Input Values Per Hectare and Outputs Given by Computer Application for Rice

\begin{tabular}{lcc}
\hline Particulars & Input Value (unit/ha) & Energy Output (MJ/ha) \\
\hline Human & $79(\mathrm{~h})$ & 154.84 \\
Animal & $00(\mathrm{~h})$ & 00 \\
Diesel & $106(\mathrm{l})$ & 5968.86 \\
Electricity & $344(\mathrm{kWh})$ & 4103.92 \\
Seed & $120(\mathrm{~kg})$ & 1764 \\
Farmyard Manure & $2501(\mathrm{~kg})$ & 750.3 \\
Fertilizer & $128(\mathrm{~kg})$ & 7756.8 \\
Chemicals & $128(\mathrm{~kg})$ & 7756.8 \\
Tractor & $9.8(\mathrm{~h})$ & 134.06 \\
Machinery & $16(\mathrm{~h})$ & 167.2 \\
Grain Yield & $5520(\mathrm{~kg} / \mathrm{ha})$ & 81144 \\
Straw Yield & $6350(\mathrm{~kg} / \mathrm{ha})$ & 79375 \\
\hline
\end{tabular}


with specific energy are shown Fig:4 and Fig:5, respectively. Table 2 depicts the different inputs involved in raising rice crop and its subsequent output as displayed by the program. However, source wise energy consumption with percentage share for rice is presented in Fig:6. It is clear from these figures, electricity (34\%) was a highest input followed by fertilizer (33\%), diesel (19\%), farmyard manure $(4 \%)$, human $(4 \%)$, machinery (including tractor) $(3 \%)$, seed $(1 \%)$ and chemical $(2 \%)$. Total input energy involved for rice was 23773.84 $\mathrm{MJ} /$ ha as calculated by the software. The source wise energy (MJ/ha) consumption for rice is shown in Fig:10. The component of commercial energy was found to be highest $(93 \%)$ and rest was non-commercial energy. The energy from direct, indirect, renewable and non-renewable sources was 57, 43, 9 and $91 \%$,

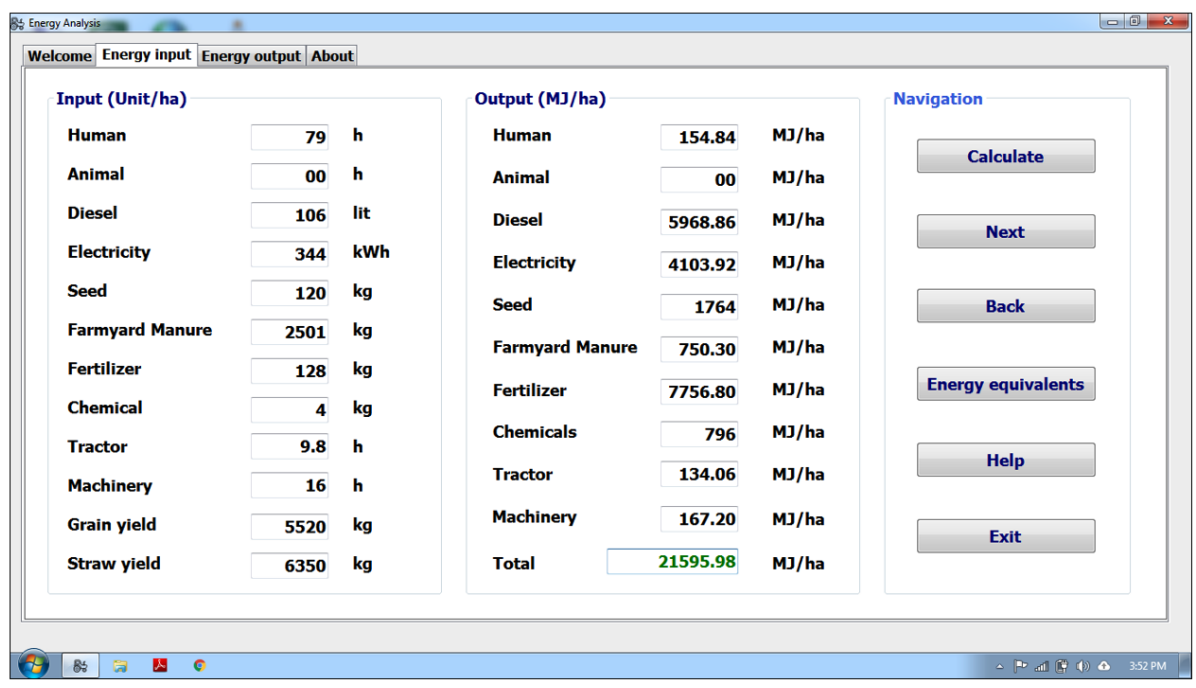

Fig:7 Energy Input Screen for Wheat Crop Production System



Fig:8 Energy Output Screen for Wheat Crop Production System 


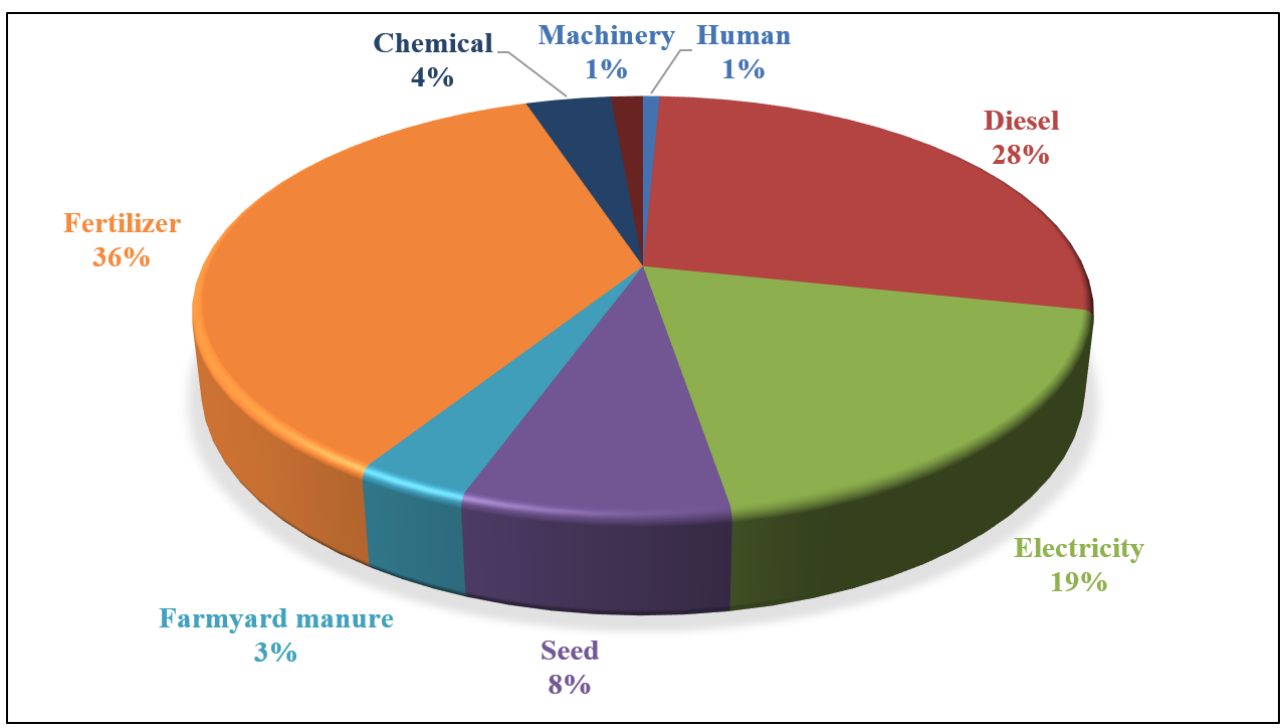

Fig:9 Source Wise Energy Consumption Percentage Share for Wheat

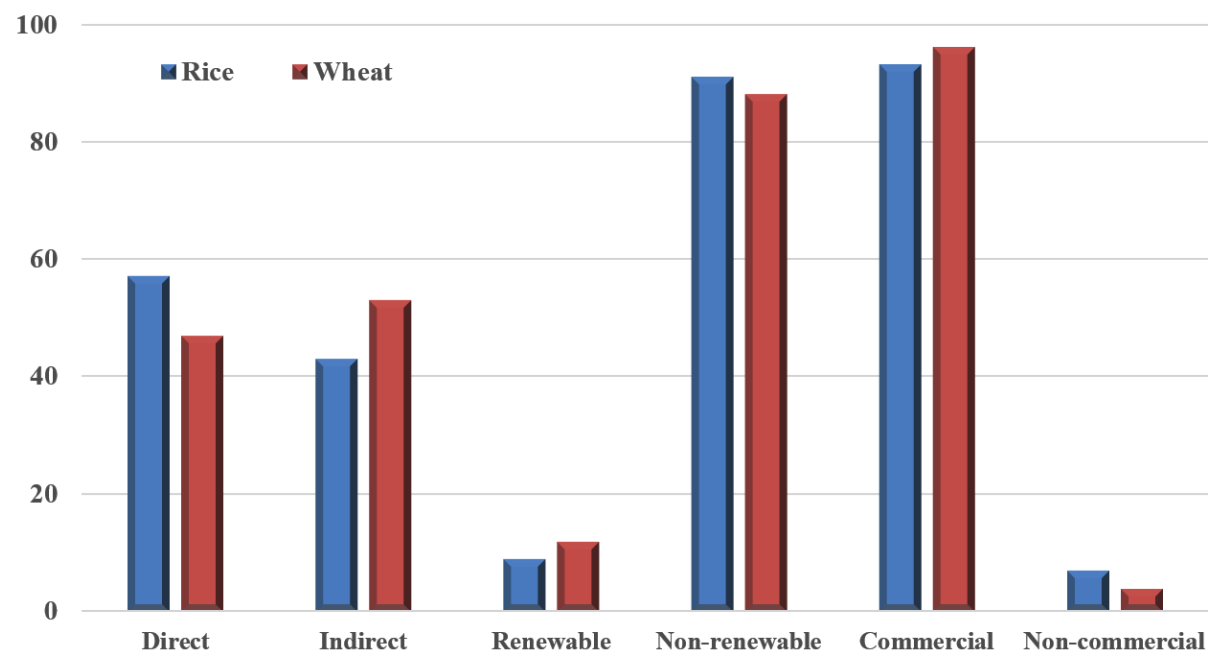

Fig. 10: Mode Wise Energy (MJ/Ha) Consumption From Different Sources of Energy in Percentage for Rice and Wheat.

respectively. From the computer application (Fig:5) energy ratio for produce and by product it was 3.69 and 2.61 , respectively. The specific energy analyzed by the computer application was $3.98 \mathrm{MJ} / \mathrm{kg}$ for rice production system.

\section{Energy in Wheat Cultivation}

While validating the computer application the wheat production systems was considered for
Indo-Gangetic Plains where rotavator is used as a seed bed preparation machine. Table 4 depicts the different output energy values as calculated by computer application against the respective input data. The percentage source wise energy share for raising wheat is presented in Fig:9. It is clearly shown that fertilizer $(36 \%)$ was a major source of energy followed by diesel (28\%) electricity (19\%) and seed ( $8 \%)$. The remaining was chemical (4\%), 
farmyard manure (3\%), machinery (including tractor) $(1 \%)$ and human (1\%). Fig:10 shows percentage share by commercial was highest $(96 \%)$ and rest had non-commercial source of energy. The energy from different modes such as direct, indirect, renewable and non-renewable was 47, 53, 12 and $88 \%$, respectively. Fig:8 showed the energy ratio for produce and by product as 3.76 and 3.66, respectively. However, specific energy was found to be $3.91 \mathrm{MJ} / \mathrm{kg}$ using the developed software.

Therefore, it was concluded that developed computer application performed well to achieve desired energy output ratios in accordance with energy equivalents on energy use pattern and consumption in different cropping systems.

\section{Conclusion}

From the study, following conclusions can be drawn:
Using the developed computer application for energy requirement in rice-wheat cropping system was efficiently analyzed and required data was obtained on the basis of different energy sources.

The developed package was used to analyze the data regarding system efficiency with respect to output energy (MJ/ha), energy ratio and specific energy $(\mathrm{MJ} / \mathrm{kg})$.

The validation of the computer application with a case study shows its usefulness in predicting the energy requirement in the rice-wheat cropping system and it would help in deciding the appropriate energy source utillization.

\section{Acknowledgement}

This research received no specific grant from any funding agency in the public, commercial, or notfor-profit sectors.

\section{References}

1. Alam, M. S., Alam, M. R., Islam, K. K. Energy Flow in Agriculture: Bangladesh. Am. J. Environ. Sci. 2005; 1(3): 213-20

2. Jha, G. K., Pal, S., Singh, A. Changing energyuse pattern and the demand projection for Indian agriculture. Agril. Econ. Res. Rev. 2012; 25(1): 61-68.

3. Mahajan, A., Gupta, R. D.: Integrated Nutrient Management (INM) in a Sustainable RiceWheat Cropping System. Springer, Dordrecht. 2009.

4. Anonymous. Agricultural statistics at a glance 2016. Department of Agriculture, Cooperation \& Farmers Welfare, Directorate of Economics and Statistics. Ministry of Agriculture \& Farmers Welfare, Government of India, 2017a; pp 89-279.

5. Anonymous. Pocket book of Agricultural Statistics 2016. Department of Agriculture, Cooperation \& Farmers Welfare, Directorate of Economics and Statistics. Ministry of Agriculture \& Farmers Welfare, Government of India, 2017b; pp 133-136.

6. Chaudhary, V., Gangwar, B., Pandey, D. Auditing of energy use and output of different cropping systems in India. Agric. Eng. Int: CIGR. J. 2006; 8: 1-13.

7. Dave, A. K., Ali, M., Mishra, B. P. Conservation tillage machinery system for cultivation of wheat in Chhattisgarh. Agril. Engg. Today. 2011; 35(2): 17-21.

8. Parmar, R. P., Verma, A. Computer program for energy requirement of sugarcane production. Sci. J. Agril. Engg. 2017, XLII (3): 29-36.

9. Nassiri, S. M., Singh, S. Study on energy use efficiency for paddy crop using data envelopment analysis (DEA) technique. Appl. Energy. 2009; 86(7-8): 1320-25.

10. Singh, S., Mittal, J. P.: Energy in production Agriculture. New Delhi: Mittal Publications, 1992; pp 6-12.

11. Helsel, Z.: Energy and alternatives for fertilizer and pesticide use In: Energy in farm production. Amsterdam: Elsevier Science Publishing, 1992; pp 177-210.

12. Yadav, S. N., Chandra, R., Khura, T. K., Chauhan, N. S. Energy input-output analysis and mechanization status for cultivation of rice and maize crops in Sikkim. Agric. Eng. Int: CIGR. J. 2013; 15(3): 108-11. 